\title{
INFLUENCE OF THE DURATION OF FEEDING PHASE ON THE GENOTYPIC STRUCTURE OF BACTERIAL COMMUNITIES IN TWO SEQUENCING BATCH REACTORS TREATING REJECT WATER BY PARTIAL NITRITATION AND ANAMMOX
}

\begin{abstract}
Microbial community and physiochemical processes were monitored by means of denaturing gradient gel electrophoresis (PCR-DGGE) in two sequencing batch reactors (SBRs) running for partial nitritationanammox and differing in the feeding phase durations (6 h $40 \mathrm{~min}$ for SBR1 and $40 \mathrm{~min}$ for SBR2). Both

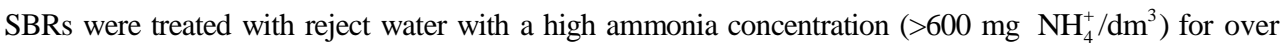
370 days. The aim of the experiment was to present the influence of this parameter on total bacterial and anammox bacterial community structure. Molecular analysis revealed that a drastic decrease in influent ammonia concentration to the studied communities caused a change of genotypic structure in their composition. The difference in the reactors working scheme can be the reason for divergence in the community structure though having no drastic influence on its performance and biodiversity level. Feeding time has stronger influence on the genotypic composition of the total bacterial community than on anammox biocenosis.
\end{abstract}

\section{INTRODUCTION}

Reject water is produced during wastewater treatment processes during the thickening, biological stabilization and dewatering of sewage sludge. It is characterized by a high ammonia nitrogen concentration $\left(0.5-1.5 \mathrm{~kg} \mathrm{NH}_{4}^{+} / \mathrm{dm}^{3}\right)$ [1] which is present due to the intensive protein ammonification in the course of sludge fermentation. Despite the fact that the volumetric reject water flow is only around $2 \%$ of the total influent wastewater, it contains $10-20 \%$ of the total nitrogen load into wastewater treatment

${ }^{1}$ The Silesian University of Technology, Faculty of Energy and Environmental Engineering, Environmental Biotechnology Department, ul. Akademicka 2, 44-100 Gliwice, Poland, corresponding author A. Ziermbińska-Buczyńska, e-mail: aleksandra.ziembinska-buczynska@polsl.pl 
plant (WWTP) [2-4]. Additionally, it is usually returned to the head of the sewage treatment which increases the energy demand for nitrification and carbon demand for denitrification. Thus, it is imperative to pre-treat the reject water before it is directed to WWTP bioreactors. This sort of wastewater is usually treated biologically but such a procedure has been found to be difficult because of the wastewater composition variability and the harm to microorganisms, thus highly damaging to community performance, which influences its effectiveness [2]. That is why constant monitoring of the bacterial community within the activated sludge during reject water treatment is both relevant and justified.

Previous research $[2,5,6]$ pointed at the possibility of partial nitritation-anammox process usage for nitrogen rich streams treatment. The high level of the ammonia nitrogen present in the wastewater was the reason why this wastewater treatment was planned to be introduced in sequencing batch reactor (SBR) system used in the study. Anammox is a relatively new process, used instead of traditional nitrification-denitrification. Ammonia is an electron donor and an effective process performance requires a nitrite-to-ammonia ratio of 1.3:1 [7]. The partial nitritation reduced to the first phase (ammonia-nitrite conversion) is needed to obtain the anammox reaction. In this experiment, both processes - partial nitritation and anammox - occurred simultaneously in one single reactor.

The increase in usage of molecular and biochemical methods for microbial ecology and bacterial changeability analysis has enabled insight into bacterial communities in their complex, dynamic and variable ecosystems, natural or technological, such as soil, water or activated sludge. Among others, PCR-DGGE seems to be an extremely useful tool allowing for the monitoring of total bacterial changeability, especially during varying wastewater treatment where recalcitrant and various technological parameters can shape the community structure [8]. It is widely known that bacterial communities in complex biological systems are flexible and can conform with ease to variable environmental conditions. In most cases such change in community structure is visible in the fingerprint pattern, but in some cases, community undergoes change at the biochemical level, where physiological adaptation occurs without visible effect in community structure [9]. Such a situation has added more and more evidence against the effect that disturbances have directly on the bacterial community [10]. That is why research performed on the bacterial community by molecular methods lets us to understand the rules by which complex ecosystems perform. PCR-DGGE fingerprints can be analyzed bioinformatically and on its basis biodiversity indexes (such as the Shannon biodiversity index) can be calculated. Such a procedure has been already performed previously for activated sludge [11-13]. In most cases, higher biodiversity is linked with better community performance.

The bacterial community of two sequencing batch bioreactors (SBRs) fed with reject water from municipal WWTP was analyzed by the PCR-DGGE method. The SBRs differed in the feeding phase duration. SBR1 was fed with the medium constantly for $6 \mathrm{~h} 40 \mathrm{~min}$, 
SBR2 - partially for $40 \mathrm{~min}$. In the SBRs, a partial nitritation-anammox process was introduced. The aim of this experiment was to compare the composition, changeability and biodiversity level of the activated sludge bacterial community in both SBRs. PCR-DGGE was used to monitor both total bacterial and the anammox community in SBRs in an over 370 day long experiment.

\section{EXPERIMENTAL}

Operational data. Both SBRs, $10 \mathrm{dm}^{3}$ in volume, were seeded with activated sludge from a municipal wastewater treatment plant in Gliwice, Poland. They were working in the configuration for 3 cycles/day at $19.2 \pm 2{ }^{\circ} \mathrm{C}$. The feeding medium was reject water from the municipal wastewater treatment plant in Gliwice, Poland. The main difference between these two reactors was in the duration of the feeding phase. In SBR1, the feeding period was $6 \mathrm{~h} 40 \mathrm{~min}$ whereas in SBR2, the feeding phase was only $40 \mathrm{~min}$. The operational scheme is shown in Fig. 1.

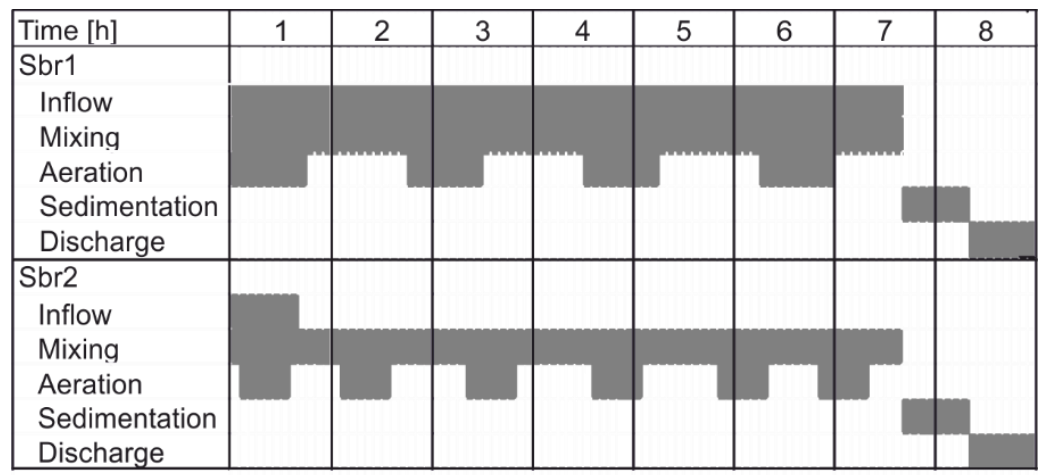

Fig. 1. SBRs performance scheme

The inflow to each reactor $\left(2 \pm 0.2 \mathrm{dm}^{3} /\right.$ cycle $)$ was provided by peristaltic pumps REGLO Digital MS (ISMATEC, Switzerland; responsible for the inflow of wastewater and outflow of treated sewage). Additionally, the system was equipped with aeration and mixing devices and was controlled by electronic and analog timers.

The standard physicochemical parameters such as: concentration of ammonia, nitrite, and nitrate nitrogen, total suspended solids (TSS), volatile suspended solids (VSS), alkalinity, phosphates, chemical oxygen demand (COD), temperature, $\mathrm{pH}$ were measured once a week. $\mathrm{NH}_{4}^{+}-\mathrm{N}, \mathrm{NO}_{2}^{-}-\mathrm{N}, \mathrm{NO}_{3}^{-}-\mathrm{N}$ as well as $\mathrm{COD}$, phosphates and alkalinity - according to Merck methodology using spectrophotometers Spectroquant NOVA320 
and Spectroquant NOVA620 (Merck, Germany). For physical parameters (pH and temperature) the $\mathrm{pH}$-meter 340i (WTW, Poland) was used. TSS and VSS were measured according to the standard method APHA.

Activated sludge sampling, DNA isolation and PCR conditions. Activated sludge samples $\left(10 \mathrm{~cm}^{3}\right.$ in volume) were collected from both SBRs, pelleted by centrifugation (5000 rpm, $10 \mathrm{~min}, 4{ }^{\circ} \mathrm{C}$ ) and stored at $-45^{\circ} \mathrm{C}$ until DNA isolation. Total genomic DNA was extracted from $0.2 \mathrm{~g}$ of the activated sludge samples using the mechanical method. The samples were washed three times with $1 \times \mathrm{PBS}$ buffer (Sigma) and disintegrated with bead beating (Roth) in lysis buffer (Tris-HCl $100 \mathrm{mM}$, EDTA $100 \mathrm{mM}$, $1.5 \mathrm{M} \mathrm{NaCl}, \mathrm{pH} 8.0)$. The samples were incubated for $20 \mathrm{~min}$ with shaking (1400 rpm) and $200 \mu 110 \%$ SDS was added. After $30 \mathrm{~min}$ of incubation at $65^{\circ} \mathrm{C}$, samples were centrifuged twice at $13000 \mathrm{rpm}$ and placed on spin filters (A\&A Biotechnology). DNA attached to the filter was washed twice with 70\% ethanol solution (A\&A Biotechnology). The concentration of DNA was measured spectrophotometrically using Qubit (Invitrogen) and stored at $-20^{\circ} \mathrm{C}$ before PCR amplification.

For PCR-DGGE, the primers with a GC clamp added to one of the primers were used. Partial 16S rRNA gene amplification of all the bacteria was performed using primers: 338f-GC (3'CGCCCGCCGCGCGCGGCGGGCGGGGCGGGG GCACGGGG GGCCT ACGGGAGGCAGCAG 5') and 518r (3'ATTACCGCGGCTGCTGG 5') [14]. As it was used in the previous studies for monitoring anammox bacteria [15], the primers: Pla46f-GC (3'GCCCGGGGCGCCCCCGGGCGGGGCGGGGGCACGGGGG GGATTAGGCATGCAAGTC 5') and 1401r (3'CGGTGTGTACAAGGCCC 5') were used. PCR reaction was performed in $30 \mu 1$ mixture with 1.5 U GoTAQ flexi Polymerase (Promega), $1 \times$ buffer, $2 \mathrm{mM} \mathrm{MgCl} 2,5 \mathrm{pmol} / \mu \mathrm{l}$ of each primers and $20 \mathrm{pmol} / \mu \mathrm{l}$ of dNTPs. Total bacterial DNA $(0.2 \mu \mathrm{g} / \mu \mathrm{l})$ from activated sludge samples was used as a DNA template. The amplification was performed in a thermocycler T-1000 (Bio-Rad) as described elsewhere $[14,15]$. The PCR products were separated in $0.8 \%(\mathrm{w} / \mathrm{v})$ agarose with ethidium bromide $\left(10 \mu \mathrm{l} / \mathrm{cm}^{3}\right.$, Promega $)$ in $1 \times \mathrm{TBE}$ buffer and visualized under UV light.

Conditions of electrophoresis of denaturing gradient gel and results analysis. The DGGE of the PCR products obtained in reactions with 338F-GC/518R and Pla46f-GC -GC/1401r primers underwent electrophoretic separation in the Dcode Universal Mutation Detection System (BioRad). Polyacrylamide gel (8\% for 16S rRNA gene, 37.5:1 acrylamide-bisacrylamide, Fluka) with a gradient of 30-60\% denaturant was prepared according to the manufacturer's instructions. The gel was run for $10 \mathrm{~h}$ at $70 \mathrm{~V}$ and $15 \mathrm{~h}$ at $65 \mathrm{~V}$ for $180 \mathrm{bp}$ and $1350 \mathrm{bp}$ fragments, respectively, in a $1 \times \mathrm{TAE}$ buffer at a constant temperature of $60{ }^{\circ} \mathrm{C}$. The gel was stained with SYBR Gold (1:10 000, Invitrogen) in MiliQ water for $30 \mathrm{~min}$ and distained in MiliQ water for $40 \mathrm{~min}$, then visualized under UV light and photographed using Quantity One 1D (BioRad). 
The analysis of DGGE fingerprints was performed using Quantity One 1D software (BioRad). Bacterial biodiversity was estimated on the basis of densitometric measurements and the Shannon diversity index as previously described [16].

DNA sequencing and bacterial identification. Well separated and strong DNA bands were excised from the DGGE gel with a sterile blade. $200 \mu \mathrm{l}$ of sterile MiliQ water was added to the bands and the probes were incubated for $30 \mathrm{~min}$ at room temperature. After incubation, water was poured out and $30 \mu \mathrm{l}$ of sterile MiliQ water was added to the probes. The excised bands were crushed and frozen at $-20{ }^{\circ} \mathrm{C}$ before reamplification.

$1 \mu 1$ DNA eluted from the DNA bands was used as a template for PCR reamplification. The PCR program consisted of the same steps as the previous one but the number of the cycles was lower ( 25 cycles). The PCR products were purified from the PCR reaction residues with Clean-Up Kit (A\&A Biotechnology) and underwent DNA sequencing using ABI Prism BigDye Terminator Cycle Sequencing Kit (Applied Biosystems).

\section{RESULTS}

Handling the reject water was problematic for WWTP for a long time operation due to the significant effect it has on the main-stream treatment line because high nitrogen
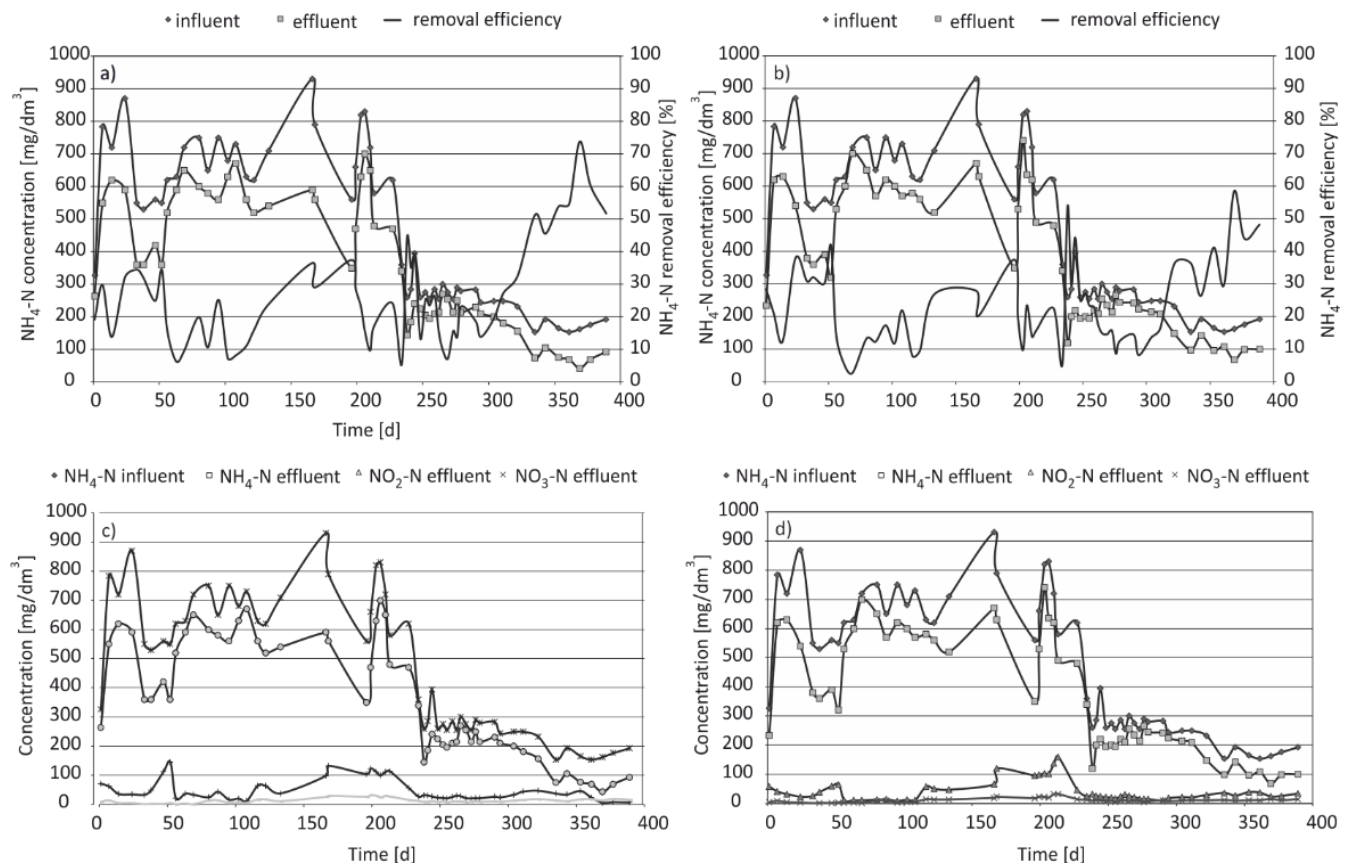

Fig. 2. Concentrations of nitrogen compounds in SBR1 (a), and SBR2 (b) ammonia removal efficacy in SBR1 (c) and SBR2 (d) during the experiment 
loads. Figures $2 \mathrm{a}$, b present the nitrogen compounds concentration changes during the total length of the experiment in both SBRs. SBR2 (Fig. 2b) seems to deal with ammonia removal better than SBR1 (Fig. 2a). For the first 230 days of the experiment the ammonia nitrogen removal was fluctuating while in the last 140 days of the experiment it increased. Ammonia removal efficacy for both SBRs is presented in Figs. 2c, d.

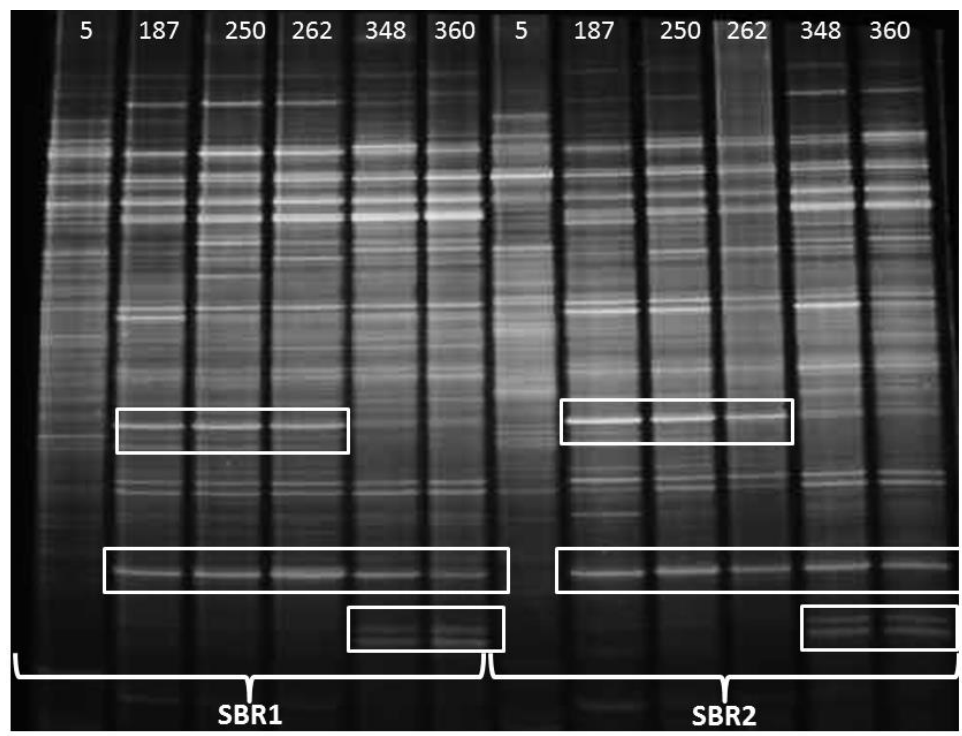

Fig. 3. DGGE fingerprints for $180 \mathrm{bp}$ amplicons for SBR1 and SBR2 from activated sludge sample in day $5,187,250,262,348$ and 360 of the experiment (dominant genotypes marked with frames)

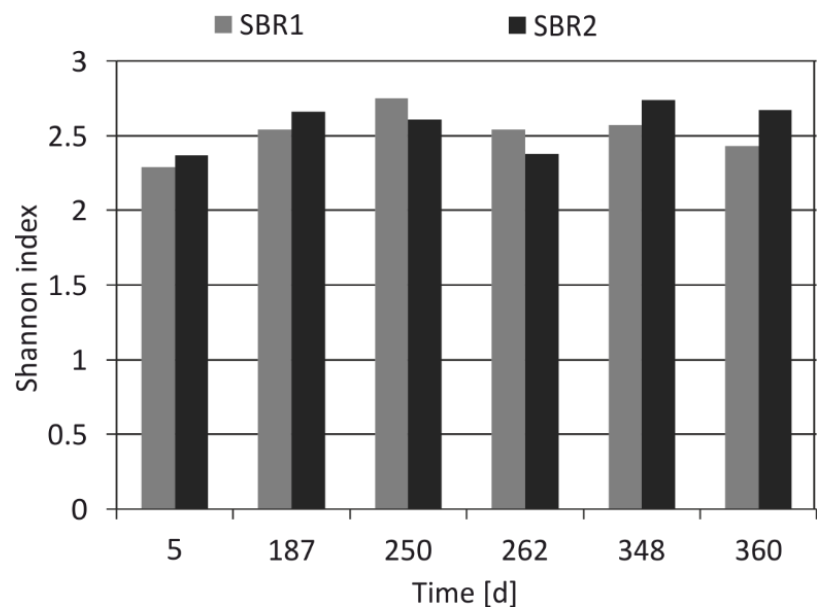

Fig. 4. Bacterial biodiversity index estimated based on the DGGE results for fragments amplified with 338f-GC and 518r for SBR1 and SBR2 from activated sludge sample in day $5,187,250,262,348$ and 360 of the experiment 
The analysis of the bacterial activated sludge community was performed for the total length of the experiment in two SBR systems differing in operational parameters. For both SBR bacterial biocenoses, PCR-DGGE analysis was performed. The DGGE monitoring of total bacterial community with 338f-GC and 518r primers is presented in Fig. 3. The Shannon biodiversity indices calculated on DGGE fingerprints are presented in Fig. 4.

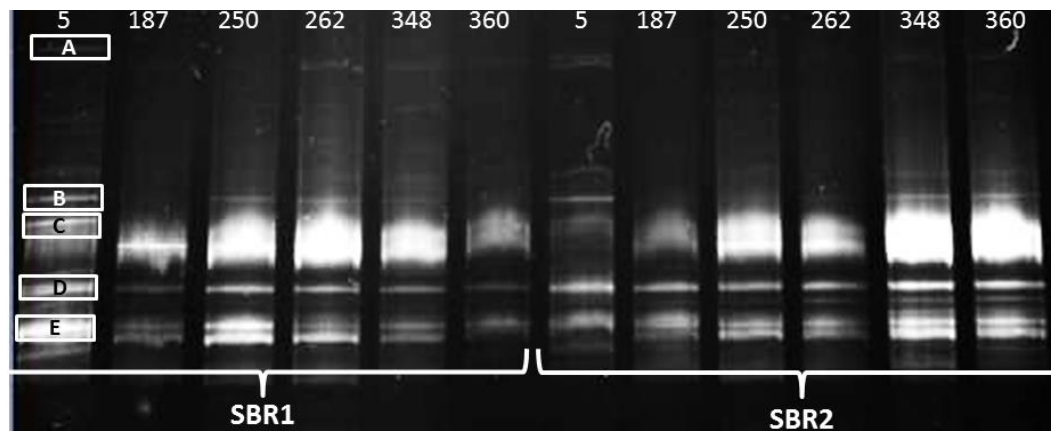

Fig. 5. DGGE fingerprints for $1450 \mathrm{bp}$ amplicons of anammox bacteria specific $16 \mathrm{~S}$ rRNA gene for SBR1 and SBR2 from activated sludge sample in day 5, 187, 250, 262, 348 and 360 of the experiment (the results of the sequencing for bands A-E are presented in Fig. 1)

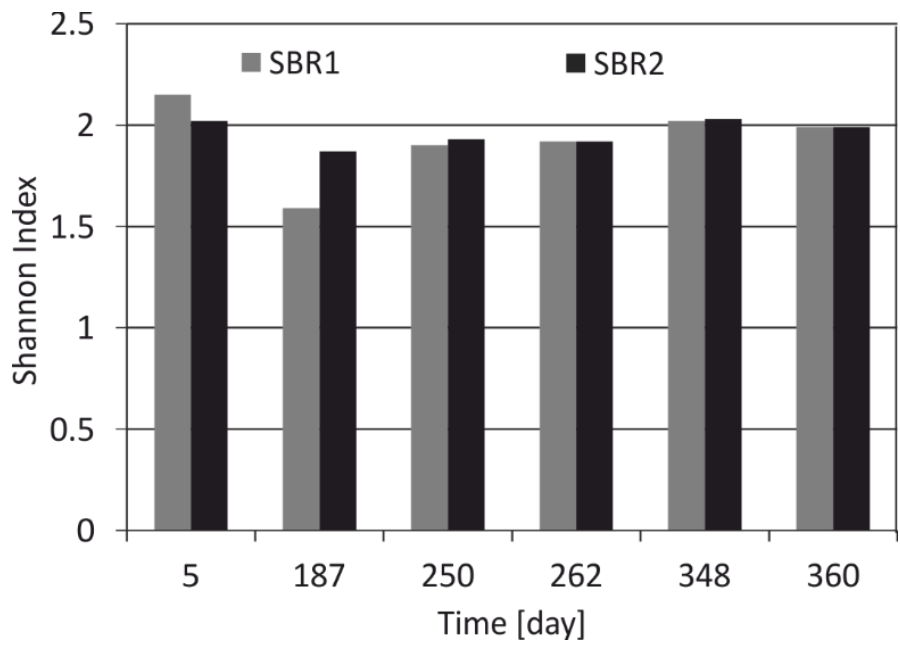

Fig. 6. Bacterial biodiversity index estimated on the basis of DGGE results for fragments amplified with Pla46f-GC and1401r for SBR1 and SBR2 from activated sludge sample in day 5, 187, 250, 262, 348 and 360 of the experiment

Due to large amount of ammonia in the reject water, the anammox process seemed to be preferable for the removal of technological ammonia nitrogen in these systems. In both SBRs bacteria performing this process were expected to be present. To prove their performance and diversity, PCR-DGGE analyses with Planctomycetes specific primers 
Pla46f-GC and 1401r were done [15]. The results of DGGE separation for anammox bacteria specific amplicons are presented in Fig. 5, and the Shannon biodiversity index for these DGGE fingerprints are given in Fig. 6. On the basis of the densitometric analysis of the PCR-DGGE fingerprints for both pairs of the primers, dendrograms using the neighbor joining method were constructed (Fig. 7).

a)

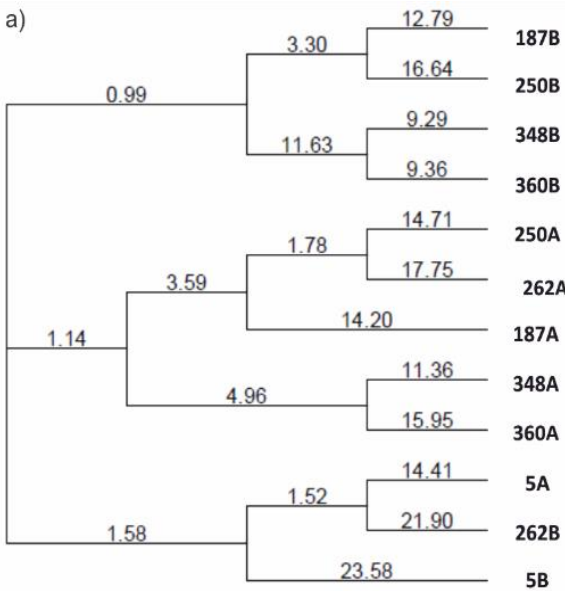

b)

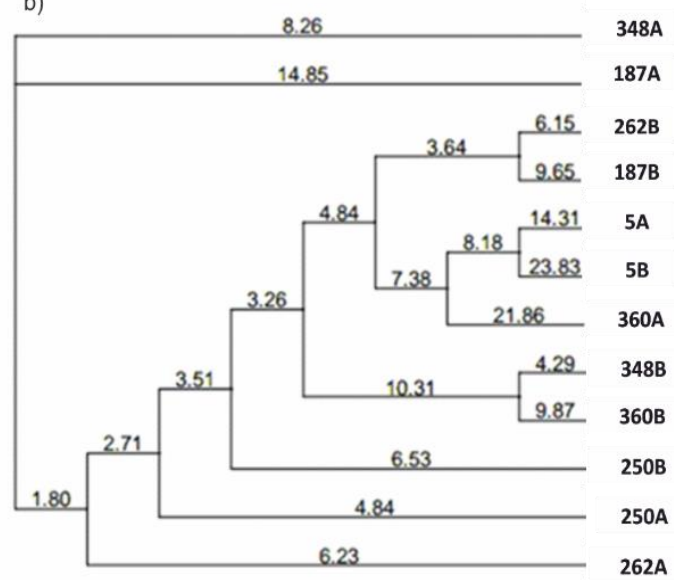

Fig. 7. The dendrogram presenting the similarity of PCR-DGGE fingerprints constructed using the neighbor joining method obtained for $180 \mathrm{bp}$ PCR products for all bacteria (a),

1350 bp PCR products for anammox bacteria (b). The samples were numbered for day 5, 187, 250, 262 and 360 of the experiment as A or B for SBR1 and SBR2, respectively

DNA bands identification based on sequence comparison with NCBI GenBank (bands A-E were cut of the gel presented in Fig. 5)

\begin{tabular}{|l|c|c|c|}
\hline \multicolumn{1}{|c|}{ NCBI sequence description } & $\begin{array}{c}\text { Simi- } \\
\text { larity } \\
{[\%]}\end{array}$ & $\begin{array}{c}\text { NCBI } \\
\text { No. }\end{array}$ & Source of the isolate \\
\hline \multicolumn{3}{|c|}{ Band A } \\
\hline $\begin{array}{l}\text { Uncultured bacterium clone 21a11 16S } \\
\text { ribosomal RNA gene, partial sequence }\end{array}$ & 75 & EF515186.1 & environmental sample \\
\hline $\begin{array}{l}\text { Uncultured bacterium clone 21h05 16S } \\
\text { ribosomal RNA gene, partial sequence }\end{array}$ & 75 & EF515247.1 & \\
\hline \multicolumn{3}{|c|}{ Band B } & \\
\hline $\begin{array}{l}\text { Uncultured bacterium clone q7774-hysa 16s } \\
\text { ribosomal RNA gene, partial sequence }\end{array}$ & 86 & JN391906.1 & $\begin{array}{l}\text { activated sludge from hybrid biofilm- } \\
\text {-activated sludge system with } \\
\text { nitrogen and phosphorus removal }\end{array}$ \\
\hline
\end{tabular}


DNA bands identification based on sequence comparison with NCBI GenBank (bands A-E were cut of the gel presented in Fig. 5)

\begin{tabular}{|c|c|c|c|}
\hline NCBI sequence description & $\begin{array}{c}\text { Simi- } \\
\text { larity } \\
{[\%]}\end{array}$ & $\begin{array}{l}\text { NCBI } \\
\text { No. }\end{array}$ & Source of the isolate \\
\hline $\begin{array}{l}\text { Uncultured sludge bacterium clone ASB29 16s } \\
\text { ribosomal RNA gene, partial sequence }\end{array}$ & 86 & FJ947131.1 & activated sludge \\
\hline $\begin{array}{l}\text { Uncultured bacterium gene for } 16 \mathrm{~S} \text { ribosomal } \\
\text { RNA, partial sequence, clone: K26C1-24 }\end{array}$ & 86 & AB504568.1 & anaerobic activate sludge \\
\hline $\begin{array}{l}\text { Uncultured bacterium clone T2-71 16s } \\
\text { ribosomal RNA gene, partial sequence }\end{array}$ & 86 & JF502993.1 & $\begin{array}{l}\text { activated sludge microbial } \\
\text { communities in full-scale } \\
\text { wastewater treatment plants }\end{array}$ \\
\hline $\begin{array}{l}\text { Uncultured Bacteroidetes bacterium 16S rRNA } \\
\text { gene from clone QEDN4BF06 }\end{array}$ & 86 & CU927760.1 & $\begin{array}{l}\text { microorganisms involved } \\
\text { in anaerobic digestion of sludge }\end{array}$ \\
\hline $\begin{array}{l}\text { Uncultured Bacteroidetes bacterium 16S rRNA } \\
\text { gene from clone QEDN4DE05 }\end{array}$ & 86 & CU927489.1 & $\begin{array}{l}\text { microorganisms involved } \\
\text { in anaerobic digestion of sludge }\end{array}$ \\
\hline $\begin{array}{l}\text { Uncultured bacterium clone N1903_75 16S } \\
\text { ribosomal RNA gene, partial sequence }\end{array}$ & 86 & EU104331.1 & activated sludge \\
\hline $\begin{array}{l}\text { Environmental 16s rDNA sequence from } \\
\text { every wastewater treatment plant anoxic basin }\end{array}$ & 86 & CU466728.1 & $\begin{array}{l}\text { activated sludge form wastewater } \\
\text { treatment plant anoxic basin }\end{array}$ \\
\hline \multicolumn{4}{|l|}{ : } \\
\hline $\begin{array}{l}\text { Uncultured bacterium isolate DGGE gel band } \\
\text { C16 16S ribosomal RNA gene, partial sequence }\end{array}$ & 84 & KC736741.1 & $\begin{array}{l}\text { activated sludge dealing with } \\
\text { oxytetracycline-containing } \\
\text { wastewater }\end{array}$ \\
\hline $\begin{array}{l}\text { Uncultured bacterium clone GL29501f02 16S } \\
\text { ribosomal RNA gene, partial sequence }\end{array}$ & 84 & HQ721145.1 & environmental samples \\
\hline $\begin{array}{l}\text { Uncultured bacterium clone Q7774-HYSA } 16 \text { S } \\
\text { ribosomal RNA gene, partial sequence }\end{array}$ & 84 & JN391906.1 & \begin{tabular}{|l} 
activated sludge from \\
hybrid biofilm \\
activated sludge system with \\
nitrogen and phosphorus removal
\end{tabular} \\
\hline $\begin{array}{l}\text { Uncultured bacterium clone T2-71 16S } \\
\text { ribosomal RNA gene, partial sequence }\end{array}$ & 84 & JF502993.1 & \begin{tabular}{|l} 
activated sludge from full-scale \\
wastewater treatment plants
\end{tabular} \\
\hline $\begin{array}{l}\text { Uncultured sludge bacterium clone ASB29 16S } \\
\text { ribosomal RNA gene, partial sequence }\end{array}$ & 84 & FJ947131.1 & lipolitic activated sludge \\
\hline $\begin{array}{l}\text { Uncultured bacterium gene for } 16 \mathrm{~S} \text { ribosomal } \\
\text { RNA, partial sequence, clone: } \mathrm{K} 26 \mathrm{C} 1-24\end{array}$ & 84 & AB504568.1 & $\begin{array}{l}\text { activated sludge } \\
\text { from anaerobic reactors }\end{array}$ \\
\hline $\begin{array}{l}\text { Uncultured Bacteroidetes bacterium 16S rRNA } \\
\text { gene from clone QEDN4BF06 }\end{array}$ & 84 & CU927760.1 & $\begin{array}{l}\text { activated sludge from anaerobic } \\
\text { digestion of sludge }\end{array}$ \\
\hline $\begin{array}{l}\text { Uncultured Bacteroidetes bacterium 16S rRNA } \\
\text { gene from clone QEDN4DE05 }\end{array}$ & 84 & CU927489.1 & anaerobic digestion of sludge \\
\hline $\begin{array}{l}\text { Uncultured bacterium clone N1903_75 16S } \\
\text { ribosomal RNA gene, partial sequence }\end{array}$ & 84 & EU104331.1 & activated sludge \\
\hline
\end{tabular}


DNA bands identification based on sequence comparison with NCBI GenBank (bands A-E were cut of the gel presented in Fig. 5)

\begin{tabular}{|l|c|c|l|}
\hline \multicolumn{1}{|c|}{ NCBI sequence description } & $\begin{array}{c}\text { Simi- } \\
\text { larity } \\
{[\%]}\end{array}$ & $\begin{array}{c}\text { NCBI } \\
\text { No. }\end{array}$ & \multicolumn{1}{|c|}{ Source of the isolate } \\
\hline $\begin{array}{l}\text { Environmental 16s rDNA sequence from } \\
\text { evry wastewater treatment plant anoxic basin }\end{array}$ & 84 & CU466728.1 & $\begin{array}{l}\text { activated sludge from anoxic } \\
\text { basin of a municipal } \\
\text { wastewater treatment plant }\end{array}$ \\
\hline & & Band D & \\
\hline $\begin{array}{l}\text { Uncultured bacterium clone SWM141 16S } \\
\text { ribosomal RNA gene, partial sequence }\end{array}$ & 86 & DQ298142.1 & silkworm midgut \\
\hline $\begin{array}{l}\text { Uncultured bacterium clone JCL9-96 16S } \\
\text { ribosomal RNA gene, partial sequence }\end{array}$ & 86 & AF499369.1 & mining-impacted lake sediments \\
\hline \multicolumn{3}{|c|}{ Band D } & \multicolumn{2}{|c|}{8} & DQ424225.1 & $\begin{array}{l}\text { lithifying and non-lithifying } \\
\text { microbial mats }\end{array}$ \\
\hline $\begin{array}{l}\text { Uncultured alpha proteobacterium clone } \\
\text { NE36B05cA 16S ribosomal RNA gene, } \\
\text { partial sequence }\end{array}$ & 88 & &
\end{tabular}

Well separated DNA bands from DGGE gel with Pla46f-GC and 1401r amplicons underwent DNA sequencing and the nucleotide sequences were compared with NCBI GenBank using MegaBlast. The results of the most probable identification are given in Table 1.

\section{DISCUSSION}

Anammox bacteria grow slowly, doubling time is ca. 11 days [17]. They are also sensitive to a long list of chemical compounds present in wastewater. That is the reason why fast anammox start-up and its efficient performance are complicated to maintain. Nonetheless, it seems wiser to try and initiate this process for reject water treatment for economic reasons $[2,5,6]$. The anammox process requires neither aeration nor an additional organic carbon source. So it would be worth trying to adapt anammox bacteria to activated sludge systems dealing with such a type of wastewater, despite the disadvantages. The analysis in the present study was focused on total bacterial community and anammox bacteria. As is presented in Figs. 2a, b, SBR1 was performing ammonia removal slightly better reaching ca. $75 \%$ of the effectiveness at the outset of the experiment, while SBR2 attained less than $60 \%$.

In order to study biodiversity changes, a 180 bp 16S rRNA gene fragment was used. Such a short fragment is more suitable for monitoring biodiversity changes, due to the fact that that PCR amplicons derive from the most variable domain of 16S rRNA coding 
gene and this guarantees a precise DGGE result $[18,19]$. The Shannon biodiversity index, calculated based on densitometric analysis of DGGE fingerprints, was higher in SBR2 than SBR1 at the beginning of the experiment. The biodiversity index for both SBRs increased during the experiment from 2.3 and 2.4 to 2.7 and 2.6 for SBR1 and SBR2, respectively, from day 5 to 250 of the experiment. These values were similar to data obtained in the previous studies [20,21]. It was probably caused by adaptation to the level of ammonia nitrogen concentration in the influent. Bacteria resistant towards a high ammonia concentration and able to perform its removal grew in the activated sludge, while the anammox bacteria biodiversity decreased slightly (Fig. 6) probably because of their slower duplication and longer adaptation times in new environmental conditions. It could be suspected that the activated sludge biocenosis needed an adaptation time lasting to day 187 of the experiment due to high ammonia concentration in the influent. After this period, the Shannon index of the total bacterial community decreased slightly to the level of 2.5 for SBR1 and 2.7 for SBR2, while anammox bacteria biodiversity increased to the initial level in day 250 of the experiment. This change can be linked with increase of the ammonia nitrogen removal efficacy (Figs. 2c, d). Between 187 and 250 day of the experiment, a stable biocenosis was obtained but with a drastic change in the ammonia concentration in the influent to a value of ca. $300 \mathrm{mg} / \mathrm{dm}^{3}$ (Figs. 2a, b). This caused a biocenosis shift without a biodiversity change, and new genotypes, not seen previously in the fingerprints, had to adapt to the new environmental conditions. Both biocenoses begin to perform efficiently after day 300 of the experiment, SBR1 slightly better than SBR2 (Figs. 2c, d). However, the genotypic composition of the total bacterial community of two SBRs changed during the experiment. As is seen in Fig. 3, fingerprints from day 187 to 200 of the experiment differ mainly in the upper part of the gel, with genotypes with lower GC content. These groups of sequences can be connected with anammox bacteria which are known to be AT-rich; and as it can be seen in Fig. 5, these genotypic changes in the DGGE fingerprints appear at a similar time as the anammox bacteria changeability. The dominant genotypes (Fig. 3, marked with frames) in the lower part of the gel seems to remain constant in both biocenoses. It should be stressed that it is important to monitor both fingerprint composition and Shannon index values because in most cases, genotype changes do not influence the biodiversity index changes. It should be also mentioned that the diversity and genotypic change of the bacterial community occurred slightly later than the changes of ammonia concentration (Figs. 2, 4 and 6). The community response to environmental changes was slower and of less significance than expected because the biocenosis was adapted to the high ammonia concentration, so decreased ammonia concentration (after 250 day of the experiment) did not influence bacteria as intensely as it could be expected otherwise. Also, bacteria living in a community can protect themselves against negative environmental factors and instead of drastic quantitative change - they rebuild the community structure to adapt to the new environmental situation. 
The anammox community was the most diverse in the beginning of the experiment. The Shannon index value was comparable for both bioreactors, slightly lower for SBR2 (2.15 and 2.02 for SBR1 and SBR2, respectively). Contrary to the total bacteria community, the anammox bacteria diversity decreased slightly between day 5 and 187 of the experiment, more notably in SBR2 than SBR1. Also the level of biodiversity was lower for anammox than for total bacterial community, probably due to the usage of PCR primers, which are specific for a relatively narrow group of bacteria, instead of the universal primers. In day 348 of the experiment, the anammox bacteria biocenoses of both SBRs reached a level comparable with the Shannon index value at the outset of the experiment.

This change was linked with the increase in the ammonia removal efficacy. In the beginning and after day 300 of the experiment, the level of the biodiversity was at a comparable level together with the higher ammonia removal effectiveness. In this case, both total bacterial and anammox bacteria diversity increased together with ammonia removal effectiveness. It could be also suspected that anammox bacteria are more sensitive towards high ammonia concentration as the biodiversity decreased at the beginning of the experiment, the previous community diversity was restored more slowly. Nonetheless, in both cases - total bacterial community and anammox bacteria community biodiversity corresponded to the level of ammonia concentration in the influent less drastic than we expected. Similar results were obtained previously for bioreactors in which CANON (completely autotrophic nitrogen removal over nitrite) was applied $[22,23]$. In these papers, it has also been stated than ammonia nitrogen concentration in the influent has a low influence on bacteria biodiversity in nitrite-anammox systems.

Figure 7 presents the neighbor joining-based dendrogram constructed on the basis of DGGE fingerprints. Samples from SBR1 and SBR2 amplified with 338f-GC and 518r primers (Fig. 7a) are clustered together, which underlines their similarity within one reactor and the difference in the community structure between both SBR systems, while initial samples (from day 5 of the experiment) are linked at the same dendrogram branch. It seems that various feeding time influenced genotypic composition of the bacterial community, creating different activate sludge biocenoses. Interestingly, sample 262B is clustered together with initial samples from both bioreactors. The genotype structure of the bacteria community can fluctuate and some genotypes can be more active than the others in the system, therefore appearing more often than the others. It could be suspected that this sample fingerprint is similar in its genotype structure to the initial community structure due to the fluctuation of the biocenosis composition.

The dendrogram constructed on the basis of Pla46f-GC/1401r PCR products seems to be more complicated (Fig. 7b). As in the case of $180 \mathrm{bp} \mathrm{16S} \mathrm{rRNA} \mathrm{gene} \mathrm{fragment}$ dendrogram initial samples are clustered together, but the sample 262B, although close, is located on the another dendrogram branch than samples 5A and 5B. Samples from SBR1 seem to be less similar than from SBR2 due to their distant location from each 
other. SBR2 samples are more condensed but not as much clustered as fingerprints obtained for $180 \mathrm{bp}$ fragments. Such a situation can be caused by less compact anammox bacteria community than the total bacterial communities' structure.

DNA bands (which genotypes are marked A-E) were cut of the gel and sequenced in order to identify them (Fig. 5). Genotype A disappeared between day 187 and 262 of the experiment, but the biocenosis genotype structure seems to be relatively constant. Interestingly, none of the DNA bands cut of the gel were identified as anammox bacteria. These results were expected due to the fact that Planctomycetes are still not well known group of bacteria and GenBank still does not possess enough 16S rRNA gene sequences belonging to these bacteria. Also the fast development of molecular tools and the common procedure of DGGE fingerprint band sequencing have caused the GenBank database to be rich in unknown and uncultured environmental clones. Nonetheless, Bands B-D were isolated from anoxic/anaerobic environments so it could be suspected that they could perform an anammox process in the environment.

\section{CONCLUSIONS}

PCR-DGGE is a sensitive tool for analysis of microbial community enabling precise monitoring of their changeability and biodiversity. However sequencing DNA bands from DGGE fingerprints did not give conclusive identification of bacteria amplified with Planctomycetes primers previously used for anammox community analysis. Such a situation occurs due to the relatively poor knowledge of the biology of these bacteria and also because of the common procedure of sequencing DNA bands and adding the bacterial sequences obtained from a large number of the environmental samples directly to GenBank. It seems that the biodiversity changes are linked more with ammonia concentration in the bioreactors influent than with the feeding time differences. It could be also suspected that various feeding time has influence on the genotypic composition of the total bacterial community more than on anammox biocenosis. Changes of the ammonia concentration in the influent did not have a drastic influence on the structure of anammox bacteria community. However, their biodiversity decreased at the beginning of the experiment while they adapted to the high ammonia concentration in the influent. The performance of both reactors slightly differed in ammonia removal efficacy, thus partial feeding is seemingly a better solution for this sort of wastewater treatment than constant feeding. Nonetheless, this statement requires further research.

\section{ACKNOWLEDGEMENT}

This work was supported by Polish Ministry of Science and Higher Education, grant No. N523 751740 and by the Faculty of Energy and Environmental Engineering, SUT, grant No. BK-271 (RIE-8) 2015. The research was performed using the equipment purchased in the project Silesian BIO-FARMA. The Center for Biotechnology, Bioengineering and Biocomputing, EFRR PO IG, 2007-2013. 


\section{REFERENCES}

[1] Kampschreur M.J., VAn der Star W.R.L. Wielders H.A., Mulder J.W., JetTen M.S.M., VAN LOOSDRECHT M.C.M., Dynamics of nitric oxide and nitrous oxide emission during full-scale reject water treatment, Water Res., 2008, 42 (3), 812.

[2] Van Hulle S., Vandeweyer B.D., Meesschaert P.A., Vanrolleghem P., Dumoulin A., Engineering aspects and practical application of autotrophic nitrogen removal from nitrogen rich streams, Chem. Eng. J., 2010, 162, 1.

[3] Mulder J.W., Van Loosdrecht M.C., Hellinga C., Van Kempen R., Full-scale application of the SHARON process for treatment of rejection water of digested sludge dewatering, Water Sci. Technol., 2001, 43 (11), 127.

[4] Van Dongen U., Jetten M.S., Van Loosdrecht M.C., The Sharon-anammox process for treatment of ammonium rich wastewater, Water Sci. Technol., 2001, 44 (1), 153.

[5] Dong Z., Sun T., Potential new process for improving nitrogen removal in constructed wetlands - promoting coexistence of partial-nitrification and anammox, Ecol. Eng., 2007, 31, 69.

[6] Joss A., Salzgeber D., Eugster J., Knig R., Rottermann K., Burger S., Fabijan P., Leumann S., MOHN J., SIEGRIST H., Full-scale nitrogen removal from digester liquid with partial nitritation and anammox in one SBR, Environ. Sci. Technol., 2009, 43, 53.

[7] Galí A., Dosta J., Macé S., Mata-Alvarez J., Comparison of reject water treatment with nitrification/denitrification via nitrite in SBR and SHARON chemostat process, Environ. Technol., 2007, 28, 173.

[8] BÜRGMANn H., JENni S., VAZQUEZ F., UdERT K.M., Regime shift and microbial dynamics in a sequencing batch reactor for nitrification and anammox treatment of urine, Appl. Environ. Microbiol., 2011, 77, 5897.

[9] Finlay B.J., MABerLy S.C., COOPER J.I., Microbial diversity and ecosystem function, Oikos, 1997, 80, 209.

[10] Allison S.D., Martiny J.B.H., Resistance, resilience, and redundancy in microbial communities, Proc. Nat. Acad. Sci. U.S.A., 2008, 105, 11512.

[11] Boon N., De Windt W., Verstraete W., TOM E.M., Evaluation of nested PCR-DGGE (denaturing gradient gel electrophoresis) with group-specific $16 S$ rRNA primers for the analysis of bacterial communities from different wastewater treatment plants, FEMS Microbiol. Ecol., 2002, 39, 2, 101.

[12] Moura A., Tacao M., Henriques I., Dias J., Ferreira P., Correia A., Characterization of bacterial diversity in two aerated lagoons of a wastewater treatment plant using PCR-DGGE analysis, Microbiol. Res., 2009, 164 (5), 560.

[13] GARrido L., SÁnchez O., FerRera I., TOMÀs N., MAS J., Dynamics of microbial diversity profiles in waters of different qualities. Approximation to an ecological quality indicator, Sci. Total Environ., 2014, 468-469, 1154.

[14] Muyzer G., De WAal E.C., Uitierlinden A.G., Profiling of complex microbial populations by denaturing gradient gel electrophoresis analysis of polymerase chain reaction-amplified genes coding for $16 S$ rRNA, Appl. Environ. Microbiol., 1993, 59, 695.

[15] InNEREBner G., Insam H., Franke-Whittle I.H., Wett B., Identification of anammox bacteria in a full-scale deammonification plant making use of anaerobic ammonia oxidation, Syst. Appl. Microbiol., 2007, 30, 408.

[16] ZIEMBIŃSKA A., CIESIELSKI S., MiKsCh K.,Ammonia oxidizing bacteria community in activated sludge monitored by denaturing gradient gel electrophoresis (DGGE), J. Gen. Appl. Microbiol., 2009, 55, 373.

[17] JIN R.-C., YANG G.-F., YU J.-J., Zheng P., The inhibition of the anammox process. A review, Chem. Eng. J., 2012, 197, 79. 
[18] GaO F., JiAng Y., XU .,X YE K., Zhou G., Changes in the composition of the bacterial flora on traypackaged pork during chilled storage analyzed by PCR-DGGE and real-time PCR, J. Food Sci., 2011, $76,27$.

[19] ZiembińsKa A., Ciesielski S., WisZniowski J., Comparison of PCR-DGGE and nested-PCR-DGGE approach for ammonia oxidizers monitoring in membrane bioreactor activated sludge, Arch. Environ. Prot., 2014, 40 (4), 41.

[20] XIA S., Li J., WANG R., Nitrogen removal performance and microbial community structure dynamics response to carbon nitrogen ratio in a compact suspended carrier biofilm reactor, Ecol. Eng., 2008, $32,256$.

[21] Liang Y., Li D., Zhang X., Zeng Z., Cui S., Zhang J., Nitrogen removal and microbial characteristics in CANON biofilters fed with different ammonia levels, Bioresour. Technol., 2014, 171, 168

[22] ZhANG X., Li D., LiANG Y., HE Y., ZhaNG Y., Zhang J., Autotrophic nitrogen removal from domestic sewage in MBR-CANON system and the biodiversity of functional microbes, Bioresour. Technol., 2013, 150, 113

[23] Liu T., Li D., Zeng H., Li X., Liang Y., Chang X., Zhang J., Distribution and genetic diversity of functional microorganisms in different CANON reactors, Bioresour. Technol., 2012, 123, 574. 